\title{
1. Introduction: re-thinking academic legal education
}

\section{Bart van Klink and Ubaldus de Vries}

In many countries across the world, the nature of the university and the purpose and function of academic education are subject to intense academic, social and political debate. The protests in cities such as Amsterdam, Hong Kong, London and Melbourne, in Spring 2015 have created a momentum to re-evaluate what the university is about and, in particular, what we want to achieve with academic education.

Both students and lecturers call for a fundamental re-evaluation of the Academia. A common thread in the protests is the resistance against the managerial culture (or 'managerialism') prevailing at universities. According to RethinkUvA (an Amsterdam based protest movement consisting of both lecturers and students), '[o]utput-focused management has severely compromised the quality of both university education and research. [...] What is called for, are 'structural reforms in education and research.' ${ }^{1}$ RethinkUU (based in Utrecht) argues that the ideals of the academic community are under pressure and warns that the 'trend toward efficiency and standardization threaten the depth and versatility of academic learning and expand bureaucracy on paper and between individuals'. ${ }^{2}$ At the London School of Economics (LSE) in London, students and lecturers oppose the current trend of neoliberalism in the academic world: 'LSE is the epitome of the neoliberal university. It is managed and organised around corporate interests, which promote

\footnotetext{
1 Available at: http://rethinkuva.org/about-rethink-uva/ (accessed 7 July 2015, our translation).

2 Available at: http://www.rethinkuu.nl/wp-content/uploads/RethinkUU. Open_Letter.English.pdf. For the original letter in Dutch, see: http://www. rethinkuu.nl/open-letter/ (both accessed 7 July 2015, our translation).
} 
elitism and perpetuate inequality.' ${ }^{3}$ OccupyLSE has started a project called the 'Free University of London', proposing that students, lecturers and workers run the university together. As The Guardian notes, the protests are directed towards the threats of 'commercialisation' and, additionally, at the threats of: efficiency, short-term interests, and at the instrumentalization of teaching and learning. ${ }^{4}$ In Quebec, students have protested in particular against funding cuts and fee increases.,56

Politicians, policymakers and university administrators seem, finally, to have heard the wake-up call. For instance, the Dutch Minister of Education, Jet Bussemakers, responded to the recent protests by confirming that academic education is 'of course' about Bildung. Moreover, Bussemakers argued that 'what is at stake is that the university enables the education of young adults to become the future driving force in our society, both nationally and internationally. ${ }^{7}$ Bussemakers' strategic vision resembles Nussbaum's idea of global citizenship (as discussed below): ${ }^{8}$

A democracy [...] exists by virtue of people who think about what kind of community we wish to be. People who give guidance as to how we want to live together in our society, what we find important and which choices follow from this. Higher education should not only educate to be able to make these choices but also to be able to lead the discussion and sharpen the debate.

Statements such as this suggest that there is a shared desire, both in the academic world and in society at large to change the course the

3 Available at: http://www.theguardian.com/higher-education-network/2015/ mar/25/university-protests-around-the-world-a-fight-against-commercialisation (accessed 7 July 2015).

4 Ibid.

5 Available at: http://theindependent.ca/2015/03/27/quebec-students-arefighting-for-you/ (accessed 20 July 2015).

6 Similar protests, about a variety of issues, took place in Melbourne, Mexico, Honduras and Hong Kong. See, respectively: http://www.theage.com.au/ victoria/thousands-of-university-students-protest-in-melbourne-against-federalbudget-20140521-38ofu.html; http://www.interaksyon.com/article/107783/ mexicans-mark-6th-month-since-43-students-vanished-with-protests; http://www. telesurtv.net/english/news/Assassination-of-4-Student-Leaders-in-Honduras-PromptsProtests-20150327-0001.html; http://blogs.wsj.com/chinarealtime/2015/03/23/inwake-of-protests-hong-kong-student-group-changes-leader/ (all accessed 20 July 2015).

7 In an interview with Science Guide, 13 March 2015; see: http://www. scienceguide.nl/201503/waar-het-echt-om-gaat.aspx (accessed 14 June 2015).

8 Available at: http://magazines.rijksoverheid.nl/ocw/ho2025/2015/01/voor woord-minister-bussemaker (accessed 7 July 2015, our translation). 
university is taking nowadays, and to rethink the true vocation of academic learning.

\section{ACADEMIC DEBATE}

In the academic world there is a lively debate going on as well. Many scholars have criticized the marketization of higher education and the reduction of the student to the role of consumer. ${ }^{9}$ Generally, academic education is perceived to be too instrumental and specialized. As many scholars observe, too much emphasis is placed on economic and career interests. ${ }^{10}$ Henry A. Giroux speaks alarmingly of 'neoliberalism's war on higher education'. ${ }^{11}$ Academic education has become skills-driven. ${ }^{12}$ According to Frank Furedi, education in general is turned into a tool of social-engineering, teaching students how to cope with the challenges of modernity by providing them with practical skills training and obligatory IT courses. ${ }^{13}$ Against the influence of so-called curriculum experts and social engineers, he advocates a pluralist approach that gives more freedom to schools and teachers to develop their own educational programs and pedagogical methods. ${ }^{14}$ Increasingly, students are put under pressure to finish their academic career fast. There is no time for students to make mistakes and detours, to grow and develop as a person and to prepare themselves to fulfil a meaningful role in society.

9 See, for instance, M Molesworth, E Nixon and R Scullion (eds), The Marketization of Higher Education and the Student as Consumer (Routledge 2011) and R Brown, Everything for Sale? The Marketization of UK Higher Education (Routledge 2013).

10 Lyana Francot \& Bald de Vries, 'Adieu Von Humboldt? Over Domme Organisaties en Slimme mensen', in: LJ Dorsman \& PJ Knegtmans (eds), Het Universitaire Bedrijf. Over Professionalisering van Onderzoek, Bestuur en Beheer (Verloren 2010) 73.

11 Henry A Giroux, Neoliberalism's War on Higher Education (Haymarket Books 2014).

12 The hype of twenty-first century skills is an example of this tendency and is illustrative of the unreflective instrumentalization of higher education. For a glossary of the notion, see: J Bellanca \& R Brandt, 21st Century Skills: Rethinking How Students Learn (Solution Tree Press 2010).

13 Frank Furedi, Wasted. Why Education Isn't Educating (Continuum 2011).

14 In the volume Waartoe is de universiteit op aarde?, edited by $\mathrm{Ad}$ Verbrugge and Jelle van Baardewijk (Boom 2014), with contributions from both lecturers and students, the autonomy of the university is also promoted against the demands of the New Public Management. 
Opposing this trend of instrumentalization, scholars such as Anthony T Kronman and Martha Nussbaum, each in their own way, call for a fundamental re-evaluation of the idea of academic education. Kronman appeals to the intrinsic value of academic education, when he observes that the 'question about life's meaning [has lost] its status as a subject of organized academic instruction and [is] pushed to the margins of professional respectability [...]. ${ }^{15}$ Due to the contemporary culture of political correctness and the modern research ideal, we can no longer, according to Kronman, speak meaningfully about the meaning of life. In order to revive this lost tradition, he advocates the reading of classical works in literature and philosophy. Whereas Kronman conceives of education as the quest for knowledge for its own sake (that is, for understanding life), Nussbaum emphasizes the social and ethical aspirations of academic education. According to her, education is needed to make students aware of ethical problems and to prepare them for global citizenship. Inspired by Kant and Stoic cosmopolitanism, Nussbaum stresses the importance of using 'the faculties of thought and imagination that make us human and make our relations rich human relations rather than relations of mere use and manipulation.' ${ }^{16}$

\section{LEGAL EDUCATION}

As the direction, function and nature of academic education are subject to intense debate inside and outside the university, this is also true for academic legal education. The debates confront law schools with fundamental questions about the nature of legal education. For what purpose(s) do we educate law students? Is legal education primarily vocational in the tradition of the American law schools? Or does it (also) have an academic mission, as it used to have in continental Europe where faculties (rather than schools) provide an academic programme at both undergraduate and graduate level?

In an extensive study of the modern law school, Carel Stolker notes that, from the perspective of other disciplines, the study of law is not taken too seriously and the law school (or law faculty) is considered to be

15 AT Kronman, Education's End: Why Our Colleges and Universities Have Given Up on the Meaning of Life (Yale University Press 2007) 7.

16 Martha Nussbaum, Not for Profit. Why Democracy Needs the Humanities (Princeton University Press 2010) 6. 
'the odd man out'. ${ }^{17}$ Why does this negative perception exist? Stolker gives several reasons, including legal education's vocational characteristic, the 'massification' of student enrolment, the normative character of legal research, as well as its implicit methodology and fluid line between research, consultancy and legal practice in which many academics are involved.

These reasons may be correct, but the same may be said about education in other disciplines, such as medicine and veterinary medicine. Possibly, this negative perception is fed by the huge emphasis on methodology and empirical-based science that dominates our thinking about the university in general. However, this should not be the only yardstick against which a discipline is measured as being more or less academic. This is, in our view, too narrow a focus. It implies a schism between the humanities on the one hand and the social and natural sciences on the other, whereas these three form the trinity of thought upon which the university is based. Moreover, it ignores the hermeneutic character of the legal discipline, and the argumentative way in which knowledge is justified and debated in the study of law, as in other disciplines of the humanities. ${ }^{18}$

As Stolker points out, there are other good reasons for considering law to be an academic discipline. These reasons have to do with the function of law. Law affects us in our daily lives and responds to social developments. Law is becoming increasingly complex and, therefore, strong analytical skills are needed to understand it in order to construe a consistent body of legal norms. In its application, it requires a constant supply of future academics (not only practitioners) to reflect upon law's (just) application and to guarantee its continued existence. Hence, Stolker concludes that 'law is a condition for civilised living [and] is far too important to be left to the profession or to the workplace only.' ${ }^{19}$ In other words, law is more than a vocational enterprise but must be studied, criticized and debated by academics who teach students not only the 'black-letter law', but also how to reflect on the nature of law and its actual functioning in society.

This is also the point of departure of this book: legal education is and should be academic. The point is, however, how to guarantee and

17 Carel Stolker, Rethinking the Law School. Education, Research, Outreach and Governance (CUP 2014) 88.

18 See Sanne Taekema, 'Relative Autonomy. A Characterisation of the Discipline of Law', in: Bart van Klink \& Sanne Taekema (eds), Law and Method. Interdisciplinary Research into Law (Mohr Siebeck 2011) 33-52.

19 Stolker op cit, 96. 
strengthen the academic character and quality of legal education on the one hand, and how to avoid that legal education and its curriculum become too much practice-oriented on the other hand: the study of black-letter law (legislation and case law) has to be firmly embedded in a social and theoretical context that opens up the possibility of developing a critical outlook on law - of 'thinking about the law'.20

This is, of course, not to say that the study of black-letter law is unwarranted. The point is rather that the preferred case study method is in itself not sufficient to meet all the requirements of what can count as an academic legal education. As James Boyd White states: ${ }^{21}$

The case method [was] a method of exploration and dialectic, a technique for discovering what is problematic in the law or in life, [but is now seen] as a way of distancing oneself from all that - a way of reducing experience to the level of summaries and outlines. The implied contract between the student and teacher shifts focus: our insistence to the student that 'You are responsible for these texts as you have never been responsible for anything in your life', all too frequently entails the acceptance of a correlative as well: 'and responsible for nothing else in the world'.

Any discipline contains 'ready knowledge', consisting of its basic concepts and theoretical assumptions, and methods. However, this knowledge of the legal system and its norms as it is, has to be questioned and problematized from both internal and external perspectives. Students have to be stimulated, encouraged and challenged in order to develop their faculty of judgment, that is, their ability to assess critically knowledge claims on their merits. A critical attitude provides insights and, hence, new knowledge. In academic legal education, this is no different: students acquire knowledge about the law and should reflect upon this knowledge to gain insight into law's operations. To become truly academic, legal education has to offer more than the traditional hermeneutic methods of interpreting the law, such as the case study method.

One thing that law students have to learn, thus, is that the law is no fixed entity and can be questioned from many perspectives. In an e-mail

20 See also: Lyana Francot \& Bald de Vries, 'Legal Education Re-Enchanted', [2006] 3(1) European Journal of Legal Education 3 (actually published in April 2007).

21 James Boyd White, 'Doctrine in a Vacuum: Reflections on What a Law School Ought (and Ought Not) to Be', [1986] 36(2) Journal of Legal Education 155 at 156 . 
exchange, our student assistant Tim Bleeker, who helped us with editing this volume, reports about his experience as a freshman:

When I started studying law, I expected law to dictate answers to legal problems in some kind of syllogistic manner. After all, law organizes power and wealth, and it even has the potential to take away individual freedom. Far-reaching as the law is, my assumption was that the rules provide legal certainty and dictate a set outcome in a particular case. This illusion I had as a freshman resulted in a particular focus on finding a 'right answer', rather than understanding the law as such.

After a while, Bleeker's motivation to learn diminished:

The pursuit of a 'single right answer' haunted me for quite some time. Eventually, my hopes on the syllogistic potential of law faded, as I could not - based on the rules and facts in 'hard cases' - consistently arrive at the same answer as the lecturer or textbook provided. At some point, frustrated, I found that my curiosity lessened as my focus shifted from understanding to memorizing.

Starting from our email exchange, Bleeker has developed his own position in the ongoing debate on academic legal education and will present his views more extensively in the concluding chapter of this book in which he also summarizes the other contributions and shows the connections between them. We believe it is important, considering the central theme of the book - academic learning - to give voice to a student. In his contribution, Bleeker gives his view on how legal education can be strengthened, building on his own experiences as a law student at Utrecht University.

\section{OUTLINE OF THE BOOK: THEORY, DIDACTIC INNOVATIONS AND LEARNING EXPERIMENTS}

In order to stimulate reflection and critical thinking, and the student's desire to learn, the teacher has a responsibility to confront students with alternative views and perspectives, with different ways of learning and being taught. This may require the teacher to experiment with different didactic avenues. Some of these avenues are introduced in this book.

A key question is to what purpose we - as law teachers - teach law and how we can achieve our educational goals. How does our teaching contribute to the students' intellectual development and their faculty of judgment? Within this broader question, the issue can be raised whether, for example, legal education has to be practice-orientated (in the sense 
that legal education consists of the study of what happens in practice, with the judge as a role model). Is there a tension between practice and academic learning that cannot be overcome? Or do they supplement each other and, if so, in what ways? What is needed for an integrated approach? In this book, we investigate the nature of academic legal education. How does the legal curriculum contribute to academic learning, both in terms of content, pedagogy and didactics? What skills are necessary for academic learning? What does a critical attitude consist of, and how can this attitude be promoted?

The contributions in this volume address these questions and, by implication, go beyond the dogmatic, black-letter law approach, which is still prevalent in many law curriculums in Europe and beyond. A brief examination of the programmes of study is illustrative to this end.

The book is divided into three parts.

Part I introduces theoretical positions of academic learning in the context of legal education. Acquiring knowledge of the existing legal norms in itself is not enough. The authors in this part address the question on the goal and purpose of academic legal education. What exactly can be required, and how this can be achieved, depends on the perspective one takes as a point of departure. Van Klink introduces the concept of skeptical legal education (SLE). Inspired by Oakeshott's ideal of liberal learning, Van Klink advocates the value of legal education for its own sake; as an introduction to established ways of understanding, evaluating and discussing the law. Building on the ancient skeptical notion of aphasia, he stresses the importance of interruptions in the learning process which temporarily halt the creation of knowledge. Francot \& Corrias excavate and reconsider the idea of Bildung as a means to effectively counter the hegemony of economic rationality. Academia needs to rebuild its core: Re-Bildung. In addition to these positions, Böning addresses, from a sociological point of view, the socializing (or institutionalizing) processes of legal training and assessment with which students are confronted and what this means for their critical potential. Bradney, on the other hand, focuses on the teacher, addressing how his or her autonomy is eroded by external forces, resulting in legal education becoming uniform and instrumentalized.

Part II includes contributions about how to teach law beyond the traditional approach focusing on conveying the law 'as it is'. The common denominator in this part is that these types, of course, open up new ways of looking at and thinking about the law. It includes contributions that report on how courses are designed with an aim to open up different perspectives as to how law can be studied and taught. Schwöbel-Patel teaches international law from a critical perspective (in 
the tradition of the Critical Legal Studies movement) with an aim to expose the hegemonic character of international law. Schwöbel-Patel asks whether the current focus on the technical practice-oriented teaching of international law should be questioned or even disrupted. She suggests a counter-hegemonic approach, employing critical pedagogy and Bildung as orientations for learning and teaching. Sokhi-Bulley has a similar aim, but intends to achieve this by teaching students to look at law from different theoretical perspectives ('camouflaged' as methodologies). She gives examples of classroom scenarios in which the interrogation and application formula is used in an attempt to make 'methodology' a less scary, and more accessible part of legal education, in order to allow students to be curious and inquisitive. Hutchinson shows the worth of empirical methodologies and knowledge. She argues that the emphasis on rules in legal education obscures the importance of facts in the determination of the law and suggests a move towards an 'evidence-based' practice of law. Van Rossum stresses the importance to enhance critical reflection on the exclusivity of legal systems. He shows how he does this in three socio-legal courses by using visuals (documentaries and images) to support the written word. Germain, finally, takes comparative law to its extreme, both in what is compared and where it is compared - in prison. It allows her to hear the voices of diversity that come out of untraditional environments and populate the law schools.

Part III includes contributions about innovations in teaching and learning experiments. The contributions in this part are meant to confront us, as readers and teachers, to think about and re-evaluate the ways in which we teach law by providing concrete examples of didactic experiments. The contributions offer a variety of practices of academic learning and teaching that seek to apply theoretical conceptions and instil the possibility of a critical attitude in students. Oomen stresses the importance of narratives by orchestrating encounters between students and teacher, using the didactic tools a liberal arts and science programme offers. Uygur emphasizes the importance of ethical awareness and the need for students to see injustices, which she achieves by creating a learning environment that confront students with prejudices about, for example, suspects and prisoners, using Foucault's mirror metaphor. Del Mar teaches students how to read case law using techniques from the visual and performing arts to show students that what is written might not always be enough to understand a case. De Vries experiments with student self-organization and the reading of fundamental texts, with an aim to open up his students' critical potential. In doing so, he urges for a critical attitude that is reflexive, in the sense that there is a task to 
uncover the self-evident assumptions in how we understand law, in order to judge whether society demands a reconsideration of law's foundational principles.

All contributions are in the concluding chapter summarized in more detail by Bleeker. He also opens up the various connections between the book's three parts and among the contributions and, subsequently, presents his view on academic legal education from a student's perspective.

The book concludes with concrete proposals for change, formulated in 14 theses. Each contributor has drafted a concrete proposal in the form of a thesis that might serve as a stepping-stone for actual change in the ways we teach law, both at course level and curriculum level.

\section{THE FUTURE OF LEGAL EDUCATION}

The main theme of the book is how the academic nature of legal education could be both guaranteed and strengthened. It also shows how lecturers, as Bradney argues, can 'use' their professional autonomy in being innovative and experimental.

The book is timely in the sense that there exists a momentum in how we want to view the university and how we reconsider the value of a university education. We hope that this momentum persists and will lead to the necessary changes of the university system in terms of finance, management, organizational structures and co-decision procedures, pedagogic visions, academic content, collegiality and career perspectives, the integration of teaching and research, and so on.

Roughly two positions on the purpose of academic legal education can be distinguished in this book: on the one side, higher education as an intrinsically academic activity - learning for the sake of learning, as espoused by Kronman - and, on the other side, higher education that instils a particular ethical and social responsibility, as argued, for instance, by Nussbaum - creating responsible democratic citizens that can shape tomorrow's world by addressing contemporary social problems. These two visions are mirrored in this book in the contributions in all three parts.

The contributions in this book offer different perspectives, ideas and theories about how to learn and teach the law. As Bleeker points out above, and will elaborate on, it is important to recognize the open texture of law and to question the case-study method aimed at discovering the 
'one-right answer'. ${ }^{22}$ The same is true for how to teach and learn the law - there is not one single best way.

What the contributions do have in common, is a focus on the so-called meta-perspectives on law: not only the traditional reflective disciplines such as legal theory, jurisprudence and ethics, and empirical disciplines such as the sociology of law and the psychology of law, but also other kinds of 'law and ...' perspectives which, for instance, integrate social theory and theories about power, communication and media. ${ }^{23}$

To be truly academic, the study of the black-letter law should, in our view, be put in a theoretical and social context that allows for reflection, skeptical detachment, critique and reflexivity. In addition, the way in which we teach law should be pluriform and innovative (however, not experimental for its own sake). This is how, in our view, the future of academic legal education can be guaranteed and strengthened.

22 Not to be confused with the Dworkian perspective on law's (in)determinacy; see: Ronald Dworkin, Law's Empire (Harvard University Press 1986). Dworkin considers the law to be determinate, consisting of an integrated whole of rules, norms and principles, in the sense that it provides the right answer to a legal question. The task is to find the right answer.

23 As discussed in Bart van Klink \& Sanne Taekema (eds), Law and Method. Interdisciplinary Research into Law (Mohr Siebeck 2011). 
Bart van Klink and Ubaldus de Vries - 9781784714895 Downloaded from PubFactory at 04/26/2023 03:17:52PM via free access 